\title{
Community structure of parasitoids Hymenoptera associated with Brassicaceae and non-crop vegetation
}

\author{
YAHERWANDI \\ Faculty of Agriculture, Andalas University, Limau Manis, Padang 25161, West Sumatra, Indonesia. Tel. +62-751-72774, Fax: +62-751-72702; email: \\ yaherwandi_04@yahoo.com
}

Manuscript received: 14 July 2011. Revision accepted: 16 February 2012.

\begin{abstract}
Yaherwandi. 2012. Community structure of parasitoids Hymenoptera associated with Brassicaceae and non-crop vegetation. Nusantara Bioscience 4: 22-26. Parasitoids Hymenoptera has an important role in agroecosystem because of their ability in suppressing pest population. Their presence in the field is seen as the key to agricultural ecosystem. The availability of non-crop vegetation can influence Their presence. Some adult parasitoids Hymenoptera require food in the form of pollen and nectar of wild flowers to ensure effective reproduction and longevity. The objective of this research was to study communities of parasitoid Hymenoptera in Brassicaceae field and non-crop vegetation around Brassicaceae fields. Samplings were conducted at two different landscape structures, i.e. Kayu Tanduak and Padang Laweh representing complex landscapes, whereas Alahan Panjang and Sungai Nanam representing simple landscapes. Insects were sampled by three trapping techniques (farmcop, sweep net, and yellow pan traps) in one line of transect for each landscape. A total of 84 species from 17 families of parasitoids Hymenoptera were collected in Brassicaceae field and non-crop vegetation. Landscape structure, flowering vegetation, and pesticide application affected the species richness, diversity and evenness of parasitoids Hymenoptera in Brassicaceae fields and non-crop vegetation.
\end{abstract}

Keywords: Brassicaceae, community structure, landscape, non-crop vegetation, parasitoid Hymenoptera.

\begin{abstract}
Abstrak. Yaherwandi. 2012. Struktur komunitas Hymenoptera parasitoid yang berasosiasi dengan tanaman Brassicaceae dan tumbuhan liar. Nusantara Bioscience 4: 22-26. Hymenoptera parasitoid memiliki peran penting dalam agroekosistem karena kemampuannya dalam menekan populasi hama. Keanekaragaman Hymenoptera parasitoid dapat dipengaruhi oleh ketersediaan vegetasi liar berbunga, karena beberapa parasitoid dewasa Hymenoptera membutuhkan serbuk sari dan nektar untuk reproduksi dan kelangsungan hidupnya. Tujuan dari penelitian ini adalah untuk mempelajari keanekaragaman Hymenoptera parasitoid pada pertanaman Brassicaceae dan tumbuhan liar di sekitarnya. Pengambilan sampel serangga dilakukan pada dua lanskap pertanian yang berbeda, yaitu Kayu Tanduak dan Padang Laweh mewakili lanskap pertanian yang kompleks, sedangkan Alahan Panjang dan Sungai Nanam mewakili lanskap pertanian yang sederhana. Koleksi sampel serangga menggunakan tiga metode yaitu farmcop, jaring serangga, dan nampan kuning. Total Hymenoptera parasitoid yang telah dikoleksi pada pertanaman Brasicaceae dan tumbuhan liar adalah 84 spesies yang termasuk ke dalam 17 famili. Struktur lansekap pertanian, tumbuhan liar berbunga, dan aplikasi pestisida mempengaruhi kekayaan, keanekaragaman dan kemerataan spesies Hymenoptera parasitoid pada pertanaman Brassicaceae dan tumbuhan liar.
\end{abstract}

Kata kunci: Brassicaceae, struktur komunitas, lanskap, tumbuhan liar, Hymenoptera parasitoid.

\section{INTRODUCTION}

Cabbage plants (Brassicaceae) such as broccoli, cabbage, cabbage flowers, petsai and caysin are vegetable commodities widely planted by farmers in Indonesia, including in West Sumatra. Vegetable commodity of West Sumatra not only meet the need in the province, but also support the need of the two neighboring provinces, namely Riau and Jambi. Brassicaceae fields in West Sumatra have a variety of problems, particularly pests and diseases.

Unfortunately, the use of pesticides in agricultural ecosystems has resulted in environmental pollution, decrease of arthropod diversity, the impoverishment of ecosystem and the emergence of pests resistant to these pesticides) We have several groups of farmers who have been producing organic vegetables in West Sumatra.
Organic farming is done in an effort to restore ecological functions (biorestoration) of various arthropods in agroecosystem. Therefore, it is necessary to find alternative controls without using pesticides, for example, by utilizing the natural enemies of insect herbivore or better known as biological control.

Biological control using parasitoids is an alternative pest control strategy that is currently being developed to replace the role of pesticides that tend to harm the environment and public health. Practical and more rational methods of Biological control have been introduced to enhance the role of parasitoid complex through habitat management.

The information on diversity, parasitization, distribution (dispersal rate) and ecological factors such as role of noncrop vegetation to influence ecology of parasitoids 
Hymenoptera in agroecosystem is important and very fundamental to the success of biological control. Information about the Hymenoptera parasitoids in Indonesia, particularly of parasitoid complex associated with Brassicaceae and non-crop vegetation is still limited.

Therefore, this study aimed to study the diversity, distribution, and abundance of parasitoids Hymenoptera associated with Brassicaceae and non-crop vegetation in different types of agricultural landscape in West Sumatra. The result of this study is expected to be used as a strong foundation for planning and development of integrated pest management (IPM) technologies in Indonesia.

\section{MATERIALS AND METHODS}

\section{Study sites}

Parasitoids Hymenoptera collection was conducted in different types of landscape of West Sumatra, Indonesia. The villages of Sungai Nanam and Alahan Panjang, Solok district represent a simple structure of agricultural landscape or agricultural ecosystems dominated by red onions fields (95\%). Kayu Tanduak village, Tanah Datar district and the village of Padang Laweh, Agam district represent a complex structure of agricultural landscape or agricultural ecosystems consisting of vegetables, rice, and corn. Description of research sites were presented in Table 1. Identification of insects materials were conducted in the Laboratory of Insect Ecology, Department of Pest and Diseases Plant, Faculty of Agriculture, Andalas University, Padang, West Sumatra, Indonesia. The research was conducted from March to November 2007.

Table 1. Description of research sites

\begin{tabular}{lll}
\hline Sites & $\begin{array}{l}\text { Altitude } \\
(\mathbf{m} \text { asl })\end{array}$ & Landscape type \\
\hline Kayu Tanduk & $800-850$ & $\begin{array}{l}\text { Complex agricultural landscape } \\
\text { mixed culture of vegetables }( \pm 60 \%), \\
\text { corn, and rice }\end{array}$
\end{tabular}

Padang Laweh 850-900 Complex agricultural landscape (mixed culture of vegetables $( \pm 60 \%)$, corn, and rice)

Alahan Panjang 850-1000 Simple agricultural landscape (monoculture of red onions $( \pm 95 \%)$, cabbage, and tomato)

\section{Brassicaceae fields}

At each agricultural landscape, a transect line approximately $1000 \mathrm{~m}$ in length was made along the existing fields. Sampling of Brassicaceae was done every $50 \mathrm{~m}$ along transect. Collection Hymenoptera parasitoid at each sample point was conducted using three methods: sweep net, suction with farmcop, and yellow pan traps.
Method of sweep net. Netting was conducted at each sample point on the transect line. Netting which was ten times double swing that includes 50 plants per sample point. Insects were caught directly inserted into the vial containing $70 \%$ alcohol.

Farmcop method. This method used a tool that consisted of a small electric vacuum cleaner which had been modified, 1.5-inch diameter plastic tube, a tool for insect traps consisting of $20 \mathrm{~cm}$ diameter bottles, a vial containing $70 \%$ alcohol, and 12 -volt batteries 60 A. Sampling was done by direct suction on all plant parts of Brassicaceae.

Yellow pan trap method. Traps were made of yellow plastic container measuring $15 \times 25 \mathrm{~cm}$ and $10 \mathrm{~cm}$ high. Yellow pan traps were installed in the middle of fields. Insects attracted to the yellow color would go into the traps. To kill the insects that perched on the traps, the traps were filled with soap water solution to reduce surface tension, so the insects that entered would drown and die. A trap was placed in each sample point and left for 24 hours. Insects caught were immediately cleaned and placed into the vial containing $70 \%$ alcohol.

\section{Wild vegetation}

Collection of parasitoid Hymenoptera on wild plants was done by sweep net method and suction with farmcop. Insects caught were directly placed into the vial containing $70 \%$ alcohol.

\section{Identification of parasitoid Hymenoptera}

Identification was done on adult parasitoid Hymenoptera. All Imago of parasitoids Hymenoptera obtained from sweep net method, farmcop, and yellow pan traps were identified to family level using Gaulet and Huber (1993). Identification at the species level was based on morphological differences or morphospecies.

\section{Data analysis}

Analyses of species diversity and abundance of parasitoid Hymenoptera were done using ShannonWienner Diversity Index, species richness and Simpson's evenness index (Magurran 1988; Ludwig and Reynolds 1988; Krebs 1999). To calculate species richness, ShannonWienner index, and Simpson's evenness index we used the program Primer for Windows version 5.

To create a smooth species accumulation curves, the number of species obtained at each sample point was randomized 50 times with the program EstimateS version 8:00. Randomization of parasitoid Hymenoptera species richness was based on Jackknife-1 estimator (Colwell 2007).

Analysis of community similarity of parasitoid Hymenoptera in Brassicaceae, other vegetables, and wild vegetation was done using Sørensen similarity index. To obtain the Sørensen similarity index we used biodiv97 programs integrated into Microsoft Exel. Further analysis of community grouping with cluster analysis (UPGMA) was done using the program of Statistica 7 for Windows (StatSoft 2007). 


\section{RESULTS AND DISCUSSION}

\section{Community of parasitoid Hymenoptera associated} Brassicaceae field and non-crops vegetation on different types of agricultural landscapes

The total number of parasitoid Hymenoptera collected on Brassicaceae and non-crops was 540 individuals consisting of 84 species and 17 families. The number of individuals, species, and families of parasitoids Hymenoptera associated Brassicaceae in the complex landscape was higher than that in the simple landscapes (Table 2). The high number of individuals, species, and the families of parasitoids Hymenoptera in complex agricultural landscapes was due to the flow of species from other habitats into Brassicaceae community. In other words, the parasitoid Hymenoptera community of Brassicaceae fields consisted of species of parasitoids Hymenoptera of rice fields, other vegetables, and non-crop vegetation (Table 4). This result was similar to that found by Yaherwandi et al. (2007) on rice fields in the Cianjur watershed, West Java.

Table 2. Number of family, individual, and species of parasitoid Hymenoptera associated with Brassicaceae fields and non-crops vegetation on different types of agricultural landscapes

\begin{tabular}{|c|c|c|c|c|}
\hline \multirow[b]{2}{*}{ Family } & \multicolumn{2}{|c|}{ Simple landscape } & \multicolumn{2}{|c|}{ Complex landscape } \\
\hline & $\begin{array}{c}\text { Brassicace } \\
\text { ae }\end{array}$ & $\begin{array}{c}\text { Non } \\
\text { crops }\end{array}$ & $\begin{array}{l}\text { Brassi- } \\
\text { caceae }\end{array}$ & Non crops \\
\hline Bethylidae & 0 & 0 & $5(1)$ & $5(1)$ \\
\hline Braconidae & $127(12)$ & $50(9)$ & $85(14)$ & $23(6)$ \\
\hline Chalcididae & $3(2)$ & $1(1)$ & 0 & 0 \\
\hline Ceraphronidae & 0 & 0 & $3(1)$ & $3(1)$ \\
\hline Diapriidae & $1(1)$ & $1(1)$ & $8(3)$ & 0 \\
\hline Encyrtidae & $2(1)$ & $2(1)$ & $17(3)$ & 0 \\
\hline Eucoilidae & $14(5)$ & $5(1)$ & $13(3)$ & $2(1)$ \\
\hline Eulophidae & $9(4)$ & $5(3)$ & $31(7)$ & $4(1)$ \\
\hline Ichneumonidae & $90(15)$ & $21(8)$ & $67(11)$ & $11(4)$ \\
\hline Megaspilidae & $3(1)$ & $3(1)$ & $4(1)$ & $4(1)$ \\
\hline Mutillidae & 0 & 0 & $2(1)$ & 0 \\
\hline Mymarommatidae & 0 & 0 & $2(1)$ & $2(1)$ \\
\hline Platygastridae & 0 & 0 & $2(1)$ & 0 \\
\hline Pteromalidae & $2(2)$ & 0 & $7(2)$ & $7(2)$ \\
\hline Scelionidae & $11(4)$ & $3(3)$ & $26(7)$ & $15(4)$ \\
\hline Torymidae & $1(1)$ & 0 & 0 & 0 \\
\hline Trichogrammatidae & 0 & 0 & $3(1)$ & 0 \\
\hline Total & $263(48)$ & $91(28)$ & $275(57)$ & $76(22)$ \\
\hline
\end{tabular}

Note: number in parentheses () is the number of species

However, the number of individuals, species, and family of parasitoid Hymenoptera collected on non-crop vegetation around Brassicaceae field was higher in simple landscapes than in complex landscapes (Table 2). These results indicate that the flow of species between Brassicaceae fields and non crop vegetation was quite high (Table 3). Alahan Panjang and Sungai Nanam are an agricultural area with simple landscape structure and application of pesticides is quite high (3 times per week), while the Padang Laweh and Kayu Tanduak are an agricultural area with a complex landscape and pesticide application once a week. The use of pesticides is scheduled three times a week, causing conditions the agroecosystem of Alahan Panjang and Sungai Nanam less suitable for natural enemies, including parasitoid Hymenoptera. The same results have been reported by Yaherwandi et al. (2008), especially at the time of pesticide application, many parasitoids took refuge in habitats of non crops around vegetable fields in Cianjur watershed West Java.

Table 3. Matrix similarity (Sørensen index) of parasitoids Hymenoptera on the Brassicaceae fields, red onions field, and non crops in a simple agricultural landscapes

\begin{tabular}{llll}
\hline Crops & Red onions & Brassicaceae & $\begin{array}{l}\text { Non- } \\
\text { crops }\end{array}$ \\
\hline Red onions & 1.00 & 0.31 & 0.38 \\
Brassicaceae & & 1.00 & 0.57 \\
Non-crops & & & 1.00 \\
\hline
\end{tabular}

Table 4. Matrix similarity (Sørensen index) of parasitoids Hymenoptera on the Brassicaceae, other vegetables, rice fields, and non-crops in a complex agricultural landscape

\begin{tabular}{lcccc}
\hline \multicolumn{1}{c}{ Crops } & $\begin{array}{c}\text { Brassicac } \\
\text { eae }\end{array}$ & Rice & $\begin{array}{c}\text { Other } \\
\text { vegetables }\end{array}$ & $\begin{array}{c}\text { Non- } \\
\text { crops }\end{array}$ \\
\hline Brassicaceae & 1.00 & 0.16 & 0.28 & 0.20 \\
Rice & & 1.00 & 0.36 & 0.18 \\
Other vegetables & & & 1.00 & 0.29 \\
Non-crops & & & & 1.00 \\
\hline
\end{tabular}

\section{Estimation of species richness of parasitoid Hymenoptera in the Brassicaceae fields}

Species accumulation curves of parasitoid Hymenoptera were still rising, but not too sharp in both landscapes (Figure 1). The numbers of species collected in simple and complex landscapes were 48 and 57 species respectively (Table 3), while the estimation results with Jackknife-1 estimator for the simple and complex landscapes were 66 and 92 species respectively (Figure 2).

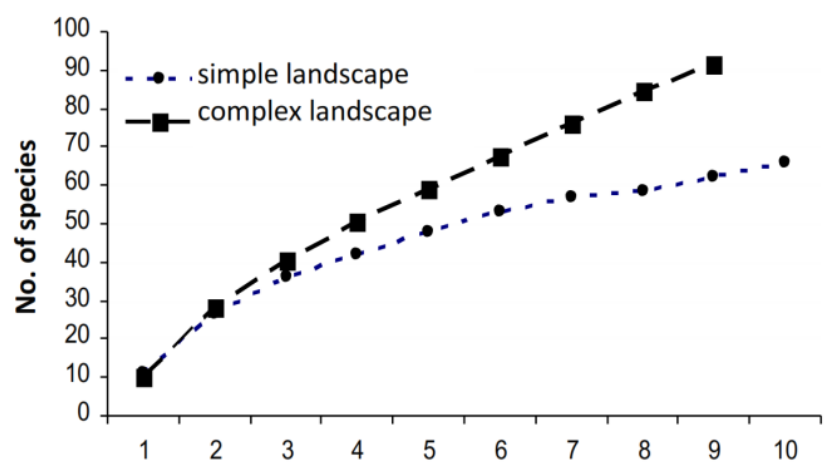

Figure 1. Accumulation curves of parasitoid Hymenoptera species on Brassicaceae fields based on data encryption of program of EstimateS 8.00 

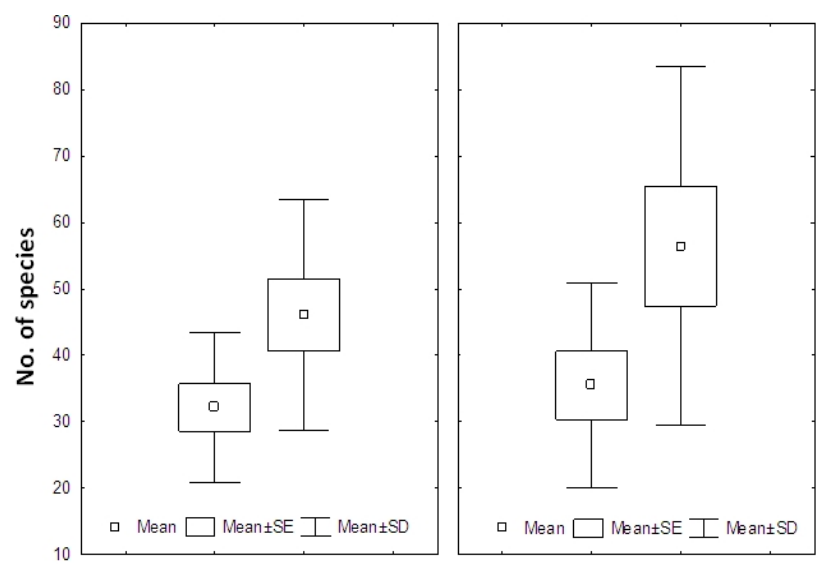

Figure 2. Number of species of parasitoids Hymenoptera in Brassicaceae fields based on observational data and Jackknife-1 estimator with program of EstimateS 8:00

This study has collected $>60 \%$ species of parasitoid Hymenoptera (Figure 2). This suggests that species richness collected was not maximal. According to Krebs (1999), the highest number of species estimated by the Jackknife estimator is twice the number of species obtained. Furthermore, He said that Jackknife-1 estimator is influenced by the total number of species, sample size and the number of unique species (rare species). Thus, the low number of species of parasitoid Hymenoptera collected was probably caused by the low number of samples (10 samples per landscape) and the ineffectiveness of tools used for collection of insects. Due to technical reasons Malaise traps were not used in this study, whereas the tool was effective enough to capture the active flying Hymenoptera (Noyes 1989; Pickering and Sharkey 1995). Many ecologists disagree with Jackknife estimator, because estimate of species richness in the community by the Jackknife estimator is biased positively or higher (overestimate) (Heltshe and Forrester 1983). However, Palmer (1990) states that the Jackknife estimator is more accurate than the eight other estimators.

\section{Species richness, evenness, and diversity index of parasitoid Hymenoptera in Brassicaceae fields}

The diversity of habitats and structure of agricultural landscape affect species richness, evenness, and diversity of parasitoid Hymenoptera. Species diversity of parasitoid Hymenoptera was higher in the complex landscape than in a simple landscape. Species diversity index is the resultant of the value of species richness and evenness. It was obvious that the high diversity of species in complex landscapes, because the species richness and evenness were high (Table 5).

Kayu Tanduak and Padang Laweh consist of a variety of habitats (rice, Brassicaceae, other vegetables, and non crops) to form the structure of agricultural landscape more complex than vegetable ecosystem in the Alahan Panjang and Sungai Nanam (dominated by red onion (95\%) and cabbage 5\%). Agricultural landscapes in Kayu Tanduak and Padang Laweh provide a variety of resources such as alternative host, food (pollen and nectar), and shelter for adult parasitoids Hymenoptera, when environmental conditions are not favorable. This agroecosystem can improve survival and diversity of parasitoid Hymenoptera. (Dryer and Landis 1996, 1997). Similar results have also been reported by Idris et al. (2007), Hooks and Johnson (2003), Menalled et al. (2003), Stephens et al. (2006), Bianchi et al. (2006), and Yaherwandi et al. (2007). The diversity of parasitoids is influenced by the type of agricultural landscape. The agricultural landscape with a complex structure has higher abundance, richness, and diversity of parasitoid species than the landscape with a simpler structure.

Table 5. Species richness, evenness, and diversity of parasitoid Hymenoptera associated with Brassicaceae crops and non-crops on different types of agricultural landscapes

\begin{tabular}{|c|c|c|}
\hline \multirow{2}{*}{ Index } & \multicolumn{2}{|c|}{ Landscape } \\
\hline & Simple & Complex \\
\hline Species richness & 46 & 56 \\
\hline Species evenness & 0.23 & 0.46 \\
\hline Species diversity & 4.23 & 5.27 \\
\hline
\end{tabular}

\section{CONCLUSION}

The complex landscape had higher number of families, individuals, and species of parasitoid Hymenoptera than the simple landscape. The number of species collected in complex and simple landscapes has reached $>60 \%$ of existing species based on Jackknife-1 estimator. Species diversity of parasitoid Hymenoptera was higher in the complex landscape than in the simple landscape. Species similarities of communities of parasitoid Hymenoptera in cabbage fields and in non-crop vegetation were $>40 \%$.

\section{ACKNOWLEDGEMENTS}

Our thanks go to the Director of Research and Community Service Director General of Higher Education, Ministry of National Education who has funded this research. We also thank the Dean and the Chairman of the Department of Plant Pests and Diseases, Faculty of Agriculture Andalas University, Padang, West Sumatra, Indonesia who have given permission to work at Laboratory of insect ecology. Our thanks were to all Wali Nagari of Kayu Tanduak, Padang Laweh, Alahan Panjang, and Sungai Nanam who gave permission to study in these four villages. Thanks were also conveyed to the students and all those who have helped this research. 


\section{REFERENCES}

Bianchi FJJA, Booij CJH, Tscharntke T. 2006. Sustainable pest regulation in agriculture landscape: a review on landscape composition, biodiversity and natural pest control. Proc R Soc B 273: 1715-1727.

Colwell RK. 2007. EstimateS: Statistical estimate of species richness and shared species from samples. Version 6.0b1 [serial online]. http://www.viceroy.eeb.uconn.edu/estimates [16 December 2003]

Dryer LE, Landis DA. 1996. Effect of habitat, temperature and sugar availability on longevity of Eriborus terebrans (Hym: Ichneumonidae). Environ Entomol 25: 1192-1201.

Dryer LE, Landis DA. 1997. influence of non-crop habitat on distribution of Eriborus terebrans (Hym: Ichneumonidae) in cornfields. Environ Entomol 26: 924-932

Goulet H, Huber JT. 1993. Hymenoptera of the world: An identification guide to families. Research Branch Agriculture Canada Publication, Ottawa.

Heltshe JE, Forrester NE. 1983. Estimating species richness using the jackknife procedure. Biometrics 39: 1-11

Hooks CR, Johnson MW. 2003. Impact of agriculture diversification on the insect community of cruciferous crops. Crop Protection 22: 223 238.

Idris AB, Nor SMd, Rohaida R. 2007. Study on diversity of insect community at different altitudes of Gunung Nuang in Selangor, Malaysia. J Biol Sci 2 (7): 505-507.
Krebs CJ. 1999. Ecological Methodology. 2nd ed. Addison Wesley Longman, New York.

Ludwig, JA, Reynolds JF. 1988. Statistical Ecology. John Wiley \& Sons, New York.

Magurran AE. 1988. Ecological diversity and its measurement. Chapman and Hall, London.

Menalled FD, Costamagna AC, Marino PC, Landis DA. 2003. Temporal variation in the response of parasitoids to agriculture landscape structure. Agric Ecosyst Environ 96: 29-35.

Noyes JS. 1989. A study of methods of sampling Hymenoptera (Insecta) in tropical rainforest, with special reference to the parasitica. J Nat Hist 23: 285-298

Palmer MW. 1990. The estimation of species richness by extrapolation. Ecology 71: 1195-1199

Statsoft [Statistical Software]. 2007. Statistica 7.0 for Windows. StatSoft, Tulsa.

Stephens CJ, Schellhorn NA, Wood GM, Austin AD. 2006. Parasitic wasp assemblages associated with native and weedy plant species in an agriculture landscape. Austr J Entomol 45: 176-184.

Yaherwandi, Manuwoto S, Buchori D, Hidayat P, Prasetyo L. 2007. Community diversity of Hymenoptera parasitoid on paddy ecosystem Jurnal HPT Tropika 7 (1): 10-20. [Indonesia]

Yaherwandi, Manuwoto S, Buchori D, Hidayat P, Prasetyo L. 2008 Community structure of Hymenoptera parasitoid on non-crop vegetations in paddy field in Cianjur watershed Jurnal HPT Tropika 8 (2): 90-101. [Indonesia] 